\title{
Induction of Systemic Resistance against Bacterial Leaf Streak Disease and Growth Promotion in Rice Plant by Streptomyces shenzhenesis TKSC3 and Streptomyces sp. SS8
}

\author{
Erneeza Mohd Hata (iD ${ }^{1 *}$, Mohd Termizi Yusof ${ }^{2}$, and Dzarifah Zulperi ${ }^{1}$ \\ ${ }^{I}$ Department of Plant Protection, Faculty of Agriculture, Universiti Putra Malaysia, 43400 UPM Serdang, Selangor, \\ Malaysia \\ ${ }^{2}$ Department of Microbiology, Faculty of Biotechnology and Biomolecular Sciences, Universiti Putra Malaysia, 43400 \\ UPM Serdang, Selangor, Malaysia
}

(Received on May 15, 2020; Revised on February 3, 2021; Accepted on March 2, 2021)

The genus Streptomyces demonstrates enormous promise in promoting plant growth and protecting plants against various pathogens. Single and consortium treatments of two selected Streptomyces strains (Streptomyces shenzhenensis TKSC3 and Streptomyces sp. SS8) were evaluated for their growth-promoting potential on rice, and biocontrol efficiency through induced systemic resistance (ISR) mediation against Xanthomonas oryzae pv. oryzicola $(\mathrm{Xoc})$, the causal agent of rice bacterial leaf streak (BLS) disease. Seed bacterization by Streptomyces strains improved seed germination and vigor, relative to the untreated seed. Under greenhouse conditions, seed bacterization with consortium treatment TKSC3 + SS8 increased seed germination, root length, and dry weight by $20 \%, 23 \%$, and $33 \%$, respectively. Single and consortium Streptomyces treatments also successfully suppressed $X o c$ infection. The result was consistent with defense-related enzyme quantification wherein single and consortium Streptomyces treatments increased peroxidase (POX), polyphenol oxidase, phenylalanine ammonia-lyase, and $\beta, 1-3$ glucanase (GLU)

\footnotetext{
*Corresponding author.

Phone) +60-397694973, FAX) +60-389381014

E-mail)erneeza@upm.edu.my

ORCID

Erneeza Mohd Hata

https://orcid.org/0000-0002-4918-9049

(c) This is an Open Access article distributed under the terms of the Creative Commons Attribution Non-Commercial License (http:// creativecommons.org/licenses/by-nc/4.0) which permits unrestricted noncommercial use, distribution, and reproduction in any medium, provided the original work is properly cited.
}

Articles can be freely viewed online at www.ppjonline.org. accumulation compared to untreated plant. Within all Streptomyces treatments, consortium treatment TKSC3 + SS8 showed the highest disease suppression efficiency $(81.02 \%)$ and the lowest area under the disease progress curve value (95.79), making it the best to control BLS disease. Consortium treatment TKSC3 + SS8 induced the highest POX and GLU enzyme activities at $114.32 \mu \mathrm{mol} / \mathrm{min} / \mathrm{mg}$ protein and $260.32 \mathrm{abs} / \mathrm{min} / \mathrm{mg}$ protein, respectively, with both enzymes responsible for plant cell wall reinforcement and resistant interaction. Our results revealed that in addition to promoting plant growth, these Streptomyces strains also mediated ISR in rice plants, thereby, ensuring protection from BLS disease.

Keywords : biocontrol agent, plant growth-promoting agent, Streptomyces, Xanthomonas oryzae pv. oryzicola

Handling Editor : Yong Hoon Lee

Rice (Oryza sativa L.) is the most widely grown crop in the world. It is a staple food for most Asian countries, and more than $80 \%$ of the world's rice is consumed by people from this region (Che Omar et al., 2019). Malaysia is a minor rice producer in Asia, accounting for only $0.4 \%$ (2.7 million tonnes) of Asia's total rice production (Herman et al., 2015). Diseases are a major constraint to rice production and bacterial leaf streak (BLS) disease, caused by Xanthomonas oryzae pv. oryzicola (Xoc) is among the most devastating bacterial pathogen of this crop (Poulin et al., 2014). This disease is widely distributed in tropical and subtropical Asian countries, including China, Thailand, 
Malaysia, India, Vietnam, the Philippines, and Indonesia (Niño-Liu et al., 2006) where yield losses range from $8-32 \%$ (Liu et al., 2014).

To date, there have been no studies explicitly conducted on BLS disease control, although many similar measures used for other bacterial rice diseases are expected to be effective against BLS (Niño-Liu et al., 2006). Cultivation of resistant varieties is one of the main strategies to control BLS disease (Khan et al., 2014), but these new varieties develop susceptibility to the disease after consecutive years of application (Ouhdouch et al., 2001). The loss of resistance among resistant varieties is due to the evolution of plant pathogens and the emergence of new pathogenic races $(\mathrm{Xu}$ et al., 2010). The application of either copper or chemical formulations as an alternative for bacterial disease control, however, has raised environmental concerns (Yang, 2010).

Microorganism communities that populate the rhizosphere are well known as plant growth and plant yield promoters (Ahkami et al., 2017). Several types of plant growth-promoting rhizobacteria (PGPR) have also been reported to trigger a salicylic acid-dependent type of induced systemic resistance (ISR) that resembles pathogeninduced systemic acquired resistance (Pieterse et al., 2014). Although ISR is triggered by PGPR colonized in the root system, the defense signal spreads systemically throughout the plant and enhances the defensive capacity of distant tissues against subsequent infections from pathogens that are active on the foliage, flower or fruit (Van Loon and Bakker, 2006).

Streptomyces is a prominent genus of actinobacteria. It is considered one of the most beneficial genera among rhizosphere microbes as it plays various functions in soil nutrient cycling and plant growth promotion (Sreevidya et al., 2016). Numerous studies have proved Streptomyces potential as a promising biocontrol agent against plant diseases, via a direct antagonistic mechanism (by secondary metabolite production) and ISR mediation (Rais et al., 2017; Suárez-Moreno et al., 2019; Viaene et al., 2016). Streptomyces as a filamentous sporulating microorganism offers the advantage of survivability under stress in unfavorable environmental conditions, and thus is frequently used as a bioinoculant for biofertiliser, phytostimulation, and biocontrol (Vurukonda et al., 2018).

Streptomyces potential as plant growth promoter and plant resistance inducer has been reported in rice (Hastuti et al., 2012; Suárez-Moreno et al, 2019) and oak (Kurth et al., 2014). However, information on Streptomyces-ISR particularly against BLS disease, is unavailable. This study was conducted to evaluate the effectiveness of selected Streptomyces strains as growth promoters in rice as well as their potential to control BLS disease through the induction of defense-related enzymes.

\section{Materials and Methods}

Streptomyces strains inoculum preparation. Two Streptomyces strains, S. shenzhenensis TKSC3 (TKSC3) and Streptomyces sp. SS8 (SS8) were selected based on a previous study (Hata et al., 2015). TKSC3 and SS8 16S rDNA sequences have been deposited in the GenBank database with accession numbers KP792984 and KP792988, respectively. These strains were kept in yeast malt broth modified with $20 \%$ glycerol and stored at $-70^{\circ} \mathrm{C}$ for long term preservation. Streptomyces strains were later revived in yeast malt broth and streaked onto International Streptomyces Project Medium-2 agar and incubated for 7 days at $30^{\circ} \mathrm{C}$. Aerial mycelium were scraped off from the agar surface using a sterile loop, suspended in sterile distilled water and the suspension filtered through cheesecloth. The spore suspension was measured using a hemocytometer, and the concentration was adjusted to $10^{6}$ spores $/ \mathrm{ml}$.

Phytopathogen inoculum preparation and plant material. Bacterial pathogen Xoc used in this study was provided by the Bacteriology Laboratory, Department of Plant Protection, Faculty of Agriculture, Universiti Putra Malaysia. The Xoc strain TKSC1 used in this study was previously characterized (Hata et al., 2019), and the GenBank accession number for the sequence is MH560793. $X o c$ culture was inoculated in peptone sucrose agar supplemented with cycloheximide $(0.05 \mathrm{~g} / \mathrm{l})$, cephalexin $(0.04 \mathrm{~g} /$ $1)$, and kasugamycin $(0.02 \mathrm{~g} / \mathrm{l})$. Plates were incubated at $28^{\circ} \mathrm{C}$ for 3 days. The $X o c$ colonies were scraped off from the agar surface, and diluted in sterile distilled water. The concentration of the pathogen suspension was adjusted to approximately $10^{7}-10^{8}$ colony forming units (cfu)/ml using a spectrophotometer (Hach DR2800, Loveland, CO, USA) at a wavelength of $660 \mathrm{~nm}$. The highly disease susceptible Malaysian rice cultivar MR219 (Zuki et al., 2020) was used throughout this study, the seeds of which were obtained from the Malaysian Agricultural Research and Development Institute (MARDI).

Influence of $S$. shenzhenensis TKSC3 and Streptomyces sp. SS8 treatment on seed germination and seedling vigor (in vitro). Fresh Streptomyces suspensions of single and consortium treatments were prepared, namely TKSC3 ( $S$. shenzhenensis TKSC3), SS8 (Streptomyces $\mathrm{sp}$. SS8), and TKSC3 + SS8 (consortium treatment of S. shenzhenensis TKSC3 and Streptomyces sp. SS8). The consortium treat- 
ment was using a 1:1 ratio of $S$. shenzhenensis TKSC3 and Streptomyces sp. SS8 suspension. Untreated seeds were negative control seeds without any Streptomyces treatment.

The delivery mode selected in this study was the seed bacterization method, as described by Chithrashree et al. (2011). Seeds were surface sterilized with $1 \%$ sodium hypochlorite $(\mathrm{NaOCl})$ prior to seed bacterization. Sterilized seeds were soaked in a fresh single (TKSC3 and SS8) and consortium (TKSC3 + SS8) Streptomyces suspensions with $10^{6}$ spores $/ \mathrm{ml}$ concentration $(0.2 \mathrm{~g} / \mathrm{ml})$. Untreated seeds were only soaked in sterile distilled water. After 6 and $12 \mathrm{~h}$ room temperature incubation, seeds were drained and dried under laminar flow.

The germination test was conducted based on the paper towel assay developed by Singh and Rao (1977). Seeds (100 seeds/treatment) were arranged and covered in paper towels $(45 \mathrm{~cm} \times 28 \mathrm{~cm}$ ), previously moistened with $25 \mathrm{ml}$ sterile distilled water. Paper towels containing the seeds were rolled up and the ends were tied with a rubber band. After 10 days of incubation at $30^{\circ} \mathrm{C}$, paper towels were unrolled and seed germination, root length, shoot length, and weight were measured. The experiment was conducted in three replicates, with each replicate containing 100 seeds. Based on these parameters, the vigor index was calculated by multiplying germination (\%) and seedling length (mm) (Abdul Baki and Anderson, 1973).

Greenhouse trial for rice growth promotion studies. An in vivo experiment was conducted in Greenhouse Field 2, Universiti Putra Malaysia. Experimental soil was obtained from the Tanjung Karang rice cultivation area in Selangor, Malaysia. The soil was sterilized using soil sterilizer (Thermoforce Ltd.) at $240 \mathrm{~V}$ for $1 \mathrm{~h}$, and $5.0 \mathrm{~kg}$ was added to each plastic pot ( $40 \mathrm{~cm}$ in diameter). The experiment was conducted in four treatments as described previously: TKSC3, SS8, TKSC3 + SS8, and untreated plants. For this experiment, treatments were delivered by two different modes: seed bacterization of $12 \mathrm{~h}$ (method as described in the previous subsection) and root-dip method (Gopalakrishnan et al., 2013). Germinated seedlings (10 days) were uprooted and the roots were dipped in the respective single and consortium Streptomyces fresh suspension (containing $10^{6}$ spores $/ \mathrm{ml}$ ) for $45 \mathrm{~min}$ and transplanted to the sterilized soil.

Randomized complete block design (RCBD) were used with five replications per treatment and 4 seedlings per replication Thirty days after transplantation, seedlings were uprooted and parameters associated with plant growth development such as seedling emergence, root length, plant height, total plant weight, and the number of tillers were measured.
Greenhouse evaluation on BLS disease control by Streptomyces treatment. Seed bacterization and the root-dip method were used as delivery methods in this experiment. A RCBD was used with three replications per treatment and four seedlings per replication. The rice plants were fertilized with NPK fertilizer on days 15 and 40 after sowing. The soil was maintained in a flooded condition until the end of the experiment.

The following treatments were included in this experiment: (1) untreated plants were infected plants without Streptomyces treatment, (2) infected plants with copperbased fungicide treatment, (3) infected plants with $S$. shenzhenensis TKSC3 treatment (TKSC3), (4) infected plants with Streptomyces sp. SS8 treatment (SS8), and (5) infected plants with $S$. shenzhenensis TKSC3 and Streptomyces sp. SS8 treatment (TKSC3 + SS8). Leaves of 40-day-old plants were spray-inoculated with $X o c$ pathogen suspension and covered with plastic for $24 \mathrm{~h}$.

Disease severity was recorded at $5,10,15$, and 20 days post inoculation (DPI). Disease severity was recorded based on the Standard Evaluation System by the International Rice Research Institute (1996). Disease severity (\%), area under the disease progress curve (AUDPC) value and disease suppression efficiency were calculated based on $\mathrm{Ji}$ et al. (2008), Adhikari and Mew (1994), and Chithrashree et al. (2011), respectively.

Assay of defense-related enzymes (peroxidase, polyphenol oxidase, phenylalanine ammonia-lyase, and $\boldsymbol{\beta}, 1-3$ glucanase). Leaves were collected at $0,2,6$, and 12 DPI and immediately homogenized with liquid nitrogen. Enzyme extraction from tissue samples were performed according to Lee et al. (2005). All enzyme assays and quantification were repeated three times. Enzyme production was quantified via absorbance reading at respective wavelengths for each of the enzymes using the Multiskan Go Spectrophotometer (Thermo Fisher Scientific, Waltham, MA, USA).

The activities of each enzyme (peroxidase [POX], polyphenol oxidase [PPO], phenylalanine ammonia-lyase [PAL], and $\beta, 1-3$ glucanase [GLU]) were calculated based on the concentration of total protein in each sample. The total protein of all leaf extracts was determined by using Bradford standard protein assay (Bradford, 1976) using bovine serum albumin as a standard. The variation in activity of defense-related enzymes, POX, PPO, PAL, and GLU were determined by enzyme assays described in Furumo and Furutani (2008), Ferraz et al. (2015), Chandrasekaran and Chun (2016), and Lever (1972), respectively. 
Statistical analysis. All statistical analyses were conducted in SAS version 9.4 (SAS Institute Inc., Cary, NC, USA). In vitro experiments were conducted in a completely randomized design. Two-way analysis of variance (ANOVA) was used to determine the effect of Streptomyces treatments and seed bacterization period and its interactions on plant growth parameters. A one-way ANOVA was conducted for the analysis of plant growth parameters (seedling emergence, radicle length, coleoptile length, dry weight roots, and vigor index) with different Streptomyces seed treatments. Means were compared using the Tukey's test, and significance was assigned at $P<0.05$.

Greenhouse experiments (plant growth promotion, disease assessment, and enzyme quantification) were performed based on RCBD. Data collected on the plant growth promotion, disease severity, AUDPC, disease suppression efficiency, and enzyme activity were subjected to one-way ANOVA, and the means were compared using the Tukey's test and significance was assigned at $P<0.05$.

\section{Results and Discussion}

In vitro seed germination and seedling vigor studies (paper towel assay). In this experiment, none of the Streptomyces strains had any phytotoxic effect on rice seeds, and all treatments resulted in a germination rate above $80 \%$. Single and consortium treatments of Streptomyces (TKSC3,
SS8, and TKSC3 + SS8) demonstrated significantly higher growth responses among all parameters evaluated (seed germination, radicle length, coleoptile length, and vigor index) compared to untreated seeds.

Streptomyces treatment, seed soaking times and their interaction significantly $(P<0.05)$ affected seed germination and coleoptiles length.Indeed, higher mean values recorded by $12 \mathrm{~h}$ seed bacterization compared to $6 \mathrm{~h}$ for all the growth parameters observed in this study. Among all treatments, TKSC 3 showed the highest value in seedling emergence, radicle length, and vigor index for both 6 and $12 \mathrm{~h}$ seed bacterization soaking times. Seedlings with Streptomyces treatment produced longer primary roots and formed an abundance of root hairs produced from the lateral roots (Fig. 1). S. shenzhenensis TKSC3 and Streptomyces sp. SS8 have been previously characterized as indole3-acetic acid (IAA) producers, $15.10 \mu \mathrm{g} / \mathrm{ml}$, and $8.91 \mu \mathrm{g} /$ $\mathrm{ml}$, respectively in a previous study (Hata et al., 2015).

IAA is a key hormone for plant growth and this study proved that Streptomyces producing IAA were capable of enhancing seedling growth by promoting primary and lateral roots as well as root hair development (Rahman et al., 2002; Viaene et al., 2016). Sharma et al. (2014) reported that Streptomyces could enhance root formation and density, thus facilitating an efficient nutrient absorption from the soil.

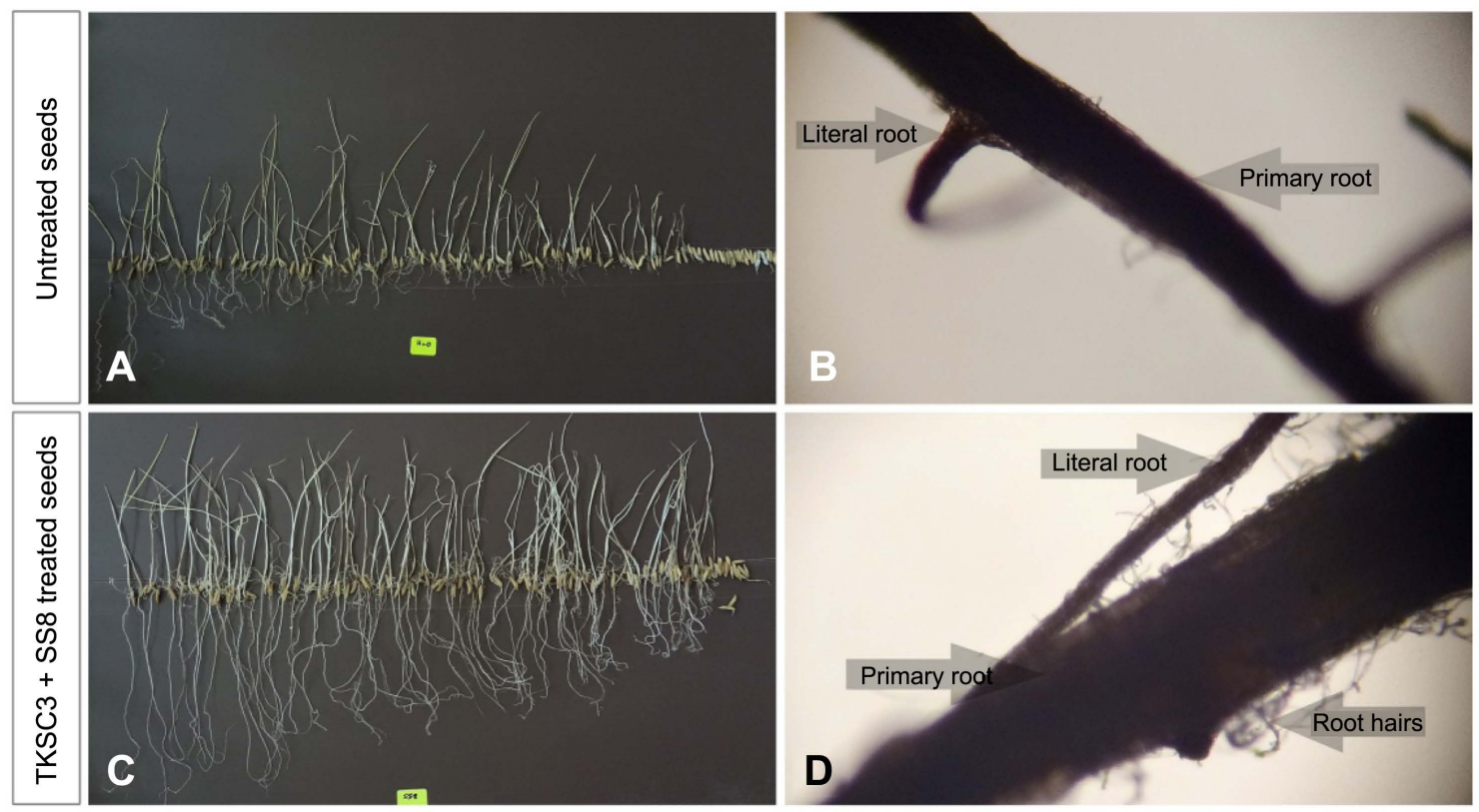

Fig. 1. Seedling growth observation from in vitro paper towel assessment (A, C) and root images captured under a compound light microscope at 4× magnification (B, D). (A, B) Untreated seeds. (C, D) Seeds treated with Streptomyces shenzhenensis TKSC3 and Streptomyces sp. SS8 (TKSC3 + SS8). Arrows indicate the primary root, lateral root, and root hair. 
Table 1. Effect of Streptomyces seed bacterization on the growth of rice seedlings under greenhouse conditions 30 days after transplantation

\begin{tabular}{lccccc}
\hline Treatment & $\begin{array}{c}\text { Seed germination } \\
(\%)\end{array}$ & $\begin{array}{c}\text { Root length } \\
(\mathrm{cm})\end{array}$ & $\begin{array}{c}\text { Plant height } \\
(\mathrm{cm})\end{array}$ & $\begin{array}{c}\text { No. of tillers } \\
\text { Dry plant weight } \\
(\mathrm{mg} / \mathrm{seedling})\end{array}$ \\
\hline Untreated seeds & $71.1 \pm 4.2 \mathrm{c}$ & $8.1 \pm 0.3 \mathrm{c}$ & $31.5 \pm 1.4 \mathrm{c}$ & $4.0 \pm 1.1 \mathrm{~b}$ & $106.7 \pm 5.4 \mathrm{~b}$ \\
TKSC3 & $83.7 \pm 3.6 \mathrm{ab}$ & $9.8 \pm 0.3 \mathrm{~b}$ & $44.0 \pm 1.5 \mathrm{a}$ & $6.0 \pm 1.5 \mathrm{a}$ & $138.0 \pm 5.3 \mathrm{ab}$ \\
SS8 & $78.3 \pm 5.3 \mathrm{bc}$ & $9.7 \pm 0.4 \mathrm{~b}$ & $40.3 \pm 2.0 \mathrm{ab}$ & $6.0 \pm 1.5 \mathrm{a}$ & $145.1 \pm 6.3 \mathrm{ab}$ \\
TKSC3 + SS8 & $88.3 \pm 5.2 \mathrm{a}$ & $10.6 \pm 0.6 \mathrm{a}$ & $42.3 \pm 2.0 \mathrm{ab}$ & $6.0 \pm 0.9 \mathrm{a}$ & $164.7 \pm 7.3 \mathrm{a}$ \\
\hline
\end{tabular}

Values are presented as mean \pm standard error of five replicates. Values followed by the same letters are not significantly different according to Tukey test at $P<0.05$.

TKSC3, Streptomyces shenzhenensis TKSC3; SS8, Streptomyces sp. SS8; TKSC3 + SS8, Streptomyces shenzhenensis TKSC3 and Streptomyces sp. SS8.

Greenhouse trial for rice growth promotion studies. Under greenhouse conditions, both single and consortium treatments of Streptomyces resulted in significantly $(P<$ 0.05 ) higher mean growth parameters for seedling emergence, radical length, coleoptile length and vigor index relative to that of untreated seeds (Table 1). However, in this greenhouse experiment, TKSC3 + SS8 consortium treatment produced the highest mean value for seed germination $(88.3 \%)$, root length $(10.6 \mathrm{~cm})$, and dry plant weight $(164.7 \mathrm{mg} / \mathrm{seedling})$. The consortium treatment enhanced seed germination by $20 \%$, root length by $23 \%$ and dry weight by $33 \%$ in rice seedlings compared to the untreated seedlings.

Our in vitro growth assessment (paper towel assay) revealed that the TKSC3 treatment as the best promoter of rice seedlings growth. However, under in vivo conditions (greenhouse trial), the consortium treatment (TKSC3 + SS8) demonstrated significantly higher mean values of seed germination, root length, and dry plant weight. In the greenhouse study, under the influence of the natural environment, both Streptomyces strains demonstrated more convincingly their ability to support rice growth.

The consortium treatment induced significantly more growth than individual strain treatments. Jha and Saraf (2012) reported that the root and shoot biomass of Jatrophacurcas $\mathrm{L}$. were maximized with a microbial consortium compared to both control and individual microorganisms. The microbial consortium has been proposed as a feasible strategy to enhance plant growth and health in commercial applications (Oluwambe and Kofoworola, 2016).

Greenhouse evaluation on BLS disease control by Streptomyces treatment. Rice plants treated with Streptomyces (either single or consortium treatments) demonstrated lower $(P<0.05)$ disease severity at all observation times $(5,10,15$, and $20 \mathrm{DPI})$ compared to untreated plants and copper-based fungicide treatment (Table 2). Untreated plants demonstrated the highest $(P<0.05)$ disease sever-

Table 2. Effect of Streptomyces spp. treatment on disease severity (on the 5, 10, 15, and 20 DPI), AUDPC, and disease suppression efficiency of Xoc inoculated plant

\begin{tabular}{|c|c|c|c|c|c|c|}
\hline \multirow{2}{*}{ Treatment } & \multicolumn{4}{|c|}{ Disease severity (\%) } & \multirow{2}{*}{ AUDPC } & \multirow{2}{*}{$\begin{array}{c}\text { Disease } \\
\text { suppression } \\
\text { efficiency }(\%)\end{array}$} \\
\hline & $5 \mathrm{DPI}$ & $10 \mathrm{DPI}$ & 15 DPI & 20 DPI & & \\
\hline Untreated plants & $20.91 \pm 0.96 \mathrm{a}$ & $33.48 \pm 0.60 \mathrm{a}$ & $47.26 \pm 1.51 \mathrm{a}$ & $59.18 \pm 2.90 \mathrm{a}$ & $603.942 \pm 10.36 \mathrm{a}$ & - \\
\hline $\begin{array}{l}\text { Copper based } \\
\text { fungicide-treated } \\
\text { plants }\end{array}$ & $19.85 \pm 2.19 \mathrm{a}$ & $34.67 \pm 1.80 \mathrm{a}$ & $33.73 \pm 1.07 \mathrm{ab}$ & $55.63 \pm 2.60 \mathrm{a}$ & $530.747 \pm 23.45 \mathrm{a}$ & $5.98 \pm 0.21 \mathrm{c}$ \\
\hline TKSC3 & $3.76 \pm 0.12 b$ & $8.18 \pm 0.82 b$ & $7.83 \pm 0.51 b$ & $15.77 \pm 0.39 b$ & $128.90 \pm 4.81 \mathrm{~b}$ & $73.20 \pm 2.70 b$ \\
\hline SS8 & $2.85 \pm 0.20 \mathrm{~b}$ & $6.86 \pm 0.57 b$ & $7.76 \pm 0.33 b$ & $13.50 \pm 0.65 b$ & $114.00 \pm 2.81 \mathrm{~b}$ & $77.02 \pm 1.95 \mathrm{ab}$ \\
\hline $\mathrm{TKSC} 3+\mathrm{SS} 8$ & $2.38 \pm 0.13 b$ & $5.68 \pm 0.34 b$ & $6.67 \pm 0.30 \mathrm{~b}$ & $11.23 \pm 0.57 \mathrm{~b}$ & $95.79 \pm 2.93 b$ & $81.02 \pm 0.47 \mathrm{a}$ \\
\hline
\end{tabular}

Values are presented as mean \pm standard error of three replicates. Values followed by the same letters are not significantly different according to Tukey test at $P<0.05$.

DPI, days post inoculation; AUDPC, area under the disease progress curve; Xoc, Xanthomonas oryzae pv. oryzicola; TKSC3, Streptomyces shenzhenensis TKSC3; SS8, Streptomyces sp. SS8; TKSC3 + SS8, Streptomyces shenzhenensis and Streptomyces sp. SS8. 
ity $(59.18 \%)$ at $20 \mathrm{DPI}$, whereas the TKSC3 $+\mathrm{SS} 8$ treated plant showed the lowest disease severity $(11.23 \%)$. The highest AUDPC (quantitative summary of disease intensity over repeated disease observations) was recorded by untreated plants) at 603.94 , followed by copper-based fungicide treated plants with 530.75. Streptomyces treatments exhibited a lower AUDPC value compared to untreated and copper based fungicide treated plants, with the lowest AUDPC shown by the consortium treatment TKSC3 + SS8 (95.79), followed by SS8 (114.00) and TKSC3 (128.90). Copper-based fungicide treated plants demonstrated the lowest $(P<0.05)$ disease protection against Xoc pathogen at $5.98 \%$. The highest protection against BLS was provided by consortium Streptomyces treatment TKSC3 + SS8 (81.02\%), followed by single treatment SS8 $(77.02 \%)$ and TKSC3 (73.20\%).

S. shenzhenensis TKSC3 and Streptomyces sp. SS8 were proven to be effective in controlling BLS disease infection.
Streptomyces spp. have been widely recognized as potential biocontrol agents, and some have been successfully developed into commercial biocontrol agents to control plant diseases. Streptomyces-based biocontrol products in the market include Mycostop (Streptomyces griseoviridis strain K61), Actinovate (Streptomyces lydicus WYEC108) and YAN TEN S. saraceticus (Streptomyces saraceticus KH400) (Olanrewaju and Babalola, 2019). In this present study, both Streptomyces strains were isolated from the rice rhizopsheres (Hata et al., 2015) and applied to the plant through seed and root dip treatment.

Advantage of Streptomyces is the morphology of these Gram positive bacteria resembles that of fungi, wherein they can form hyphae, mycelia and spores. As a filamentous and sporulating bacterium, Streptomyces can survive during unfavorable and stressful soil conditions such as drought, nutrient deficiencies and soil toxicities (Vurukonda et al., 2018).
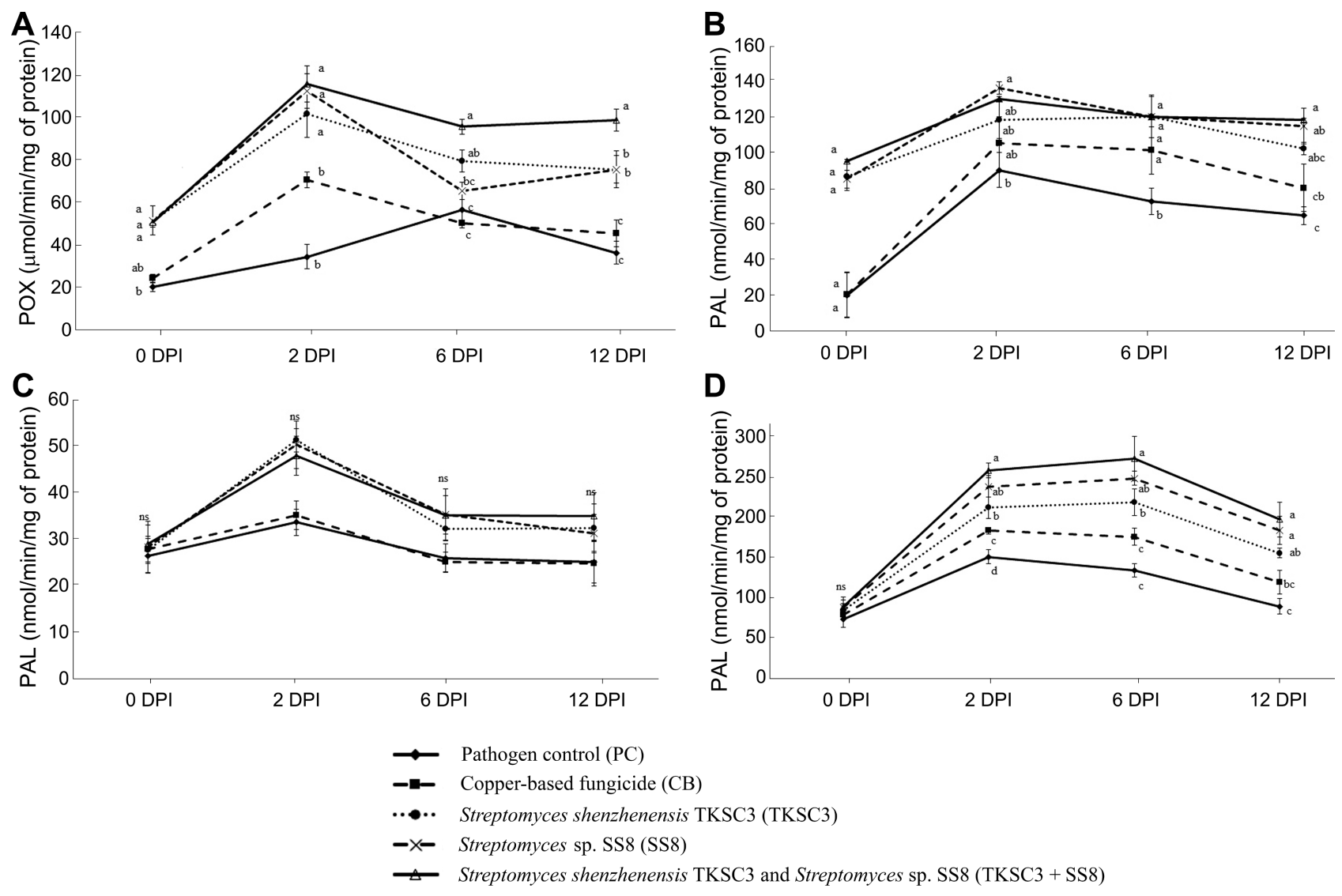

Fig. 2. Effect of Streptomyces treatments on defense-related enzymes in leaves under the stress of Xanthomonas oryzae pv. oryzicola pathogen at $0,2,6$, and 12 days post inoculation (DPI): peroxidise (POX) (A), polyphenol oxidase (PPO) (B), phenylalanine ammonialyase (PAL) (C), and $\beta, 1-3$ glucanase (GLU) (D). Bars are standard errors of the means. Bars with different letters are significantly different according to Tukey test at $P<0.05$. 'ns' denotes no statistical significance. 
Assay of defense-related enzymes (POX, PPO, PAL, and GLU). In this study, the production of defense-related enzymes was examined to determine their role in resistance reactions to infection, induced by Streptomyces treatments. Our results revealed that all Stretpomyces treatments significantly induced POX and PPO enzymes compared to the untreated and copper-based fungicide treated plants (Fig. 2). The POX activity increased upon pathogen inoculation and was at its highest at 2 DPI. The highest accumulation was $115.32 \mu \mathrm{mol} / \mathrm{min}$ of $\mathrm{mg}$ protein in the TKSC $3+\mathrm{SS} 8$ consortium treatment, which was three-fold higher than that for untreated plants. The highest activity in the PPO was at 2 DPI detected in plants treated with SS8 (136.40 $\mu \mathrm{mol} / \mathrm{min} / \mathrm{mg}$ protein), followed by TKSC3 + SS8 (130.36 $\mu \mathrm{mol} / \mathrm{min} / \mathrm{mg}$ of protein), and TKSC3 $(118.52 \mu \mathrm{mol} / \mathrm{min} /$ $\mathrm{mg}$ of protein). The highest PAL enzyme activity was also recorded at 2 DPI in the TKSC3 treatment $(51.36 \mathrm{nmol} /$ $\mathrm{min} / \mathrm{mg}$ of protein), followed by SS $8(50.36 \mathrm{nmol} / \mathrm{min} /$ $\mathrm{mg}$ of protein), and TKSC3 + SS8 $(47.99 \mathrm{nmol} / \mathrm{min} / \mathrm{mg}$ of protein) treatments. GLU enzyme activity was the highest at 6 DPI with $275.14 \mathrm{abs} / \mathrm{min} / \mathrm{mg}$ of protein accumulation induced by TKSC3 + SS8 consortium treatment. Similarly, rice plants inoculated with the pathogen alone and plants treated with copper-based fungicide showed a slight increase in defense enzyme activity upon the Xoc pathogen challenge. Thereafter, enzyme activity declined gradually to below that of Streptomyces treatments.

ISR triggered in the plant by soil, and plant microorganisms functioning for biocontrol purposes, stimulate the synthesis of defense chemicals, thus enhancing resistance against pathogens (Pal and Gardener, 2006). Previous reports provide evidence that, ISR can be elicited in plant systems by various biocontrol microorganism, for example, in tomato by Streptomyces setonii, Bacillus cereus and Serratia marcescens (Ferraz et al., 2015), rice by Bacillus (Chithrashree et al., 2011) and pepper by Bacillus pumilus (Yi et al., 2013). Our results clearly showed early and increased defense enzyme activities (POX, PPO, PAL, and GLU) in Streptomyces treated plants, leading to disease suppression in response to Xoc pathogen inoculation. Treatments triggered reactions in plant roots and signals spread systemically through the plant's system, ultimately enhancing the defensive capacity of distant tissues to subsequent infection by the pathogen (Van Loon and Bakker, 2005).

Application of Streptomyces presents enormous potential as a growth promoter and inducer of systemic resistance in rice plants against BLS disease. Streptomyces application could offer safer and sustainable alternatives to hazardous chemicals and could be incorporated into BLS disease management.

\section{Conflicts of Interest}

No potential conflict of interest relevant to this article was reported.

\section{Acknowledgments}

The authors gratefully acknowledge financial support from the Ministry of Higher Education Malaysia (MOHE) through Long-Term Research Grant Scheme (LRGS 20112016: Food Security Enhancing Sustainable Rice Production), Universiti Putra Malaysia, as well as assistance and technical support from Dr. Kamaruzaman Sijam, a former researcher in the Department of Plant Protection, Faculty of Agriculture, UPM.

\section{References}

Abdul-Baki, A. A. and Anderson, J. D. 1973. Vigour determination in soybean seed by multiple criteria. Crop Sci. 13:630633.

Adhikari, T. B. and Mew, T. M. 1994. Resistance of rice to Xanthomonas oryzae pv. oryzae in Nepal. Plant Dis. 78:64-67.

Ahkami, A. H., White, R. A. III, Handakumbura, P. P. and Jansson, C. 2017. Rhizosphere engineering: enhancing sustainable plant ecosystem productivity. Rhizosphere 3:233-243.

Bradford, M. M. 1976. A rapid and sensitive method for the quantitation of microgram quantities of protein utilizing the principle of protein-dye binding. Anal. Biochem. 72:248-254.

Chandrasekaran, M. and Chun, S. C. 2016. Expression of PRprotein genes and induction of defense-related enzymes by Bacillus subtilis CBR05 in tomato (Solanum lycopersicum) plants challenged with Erwinia carotovora subsp. carotovora. Biosci. Biotechnol. Biochem. 80:2277-2283.

Che Omar, S., Shaharudin, A. and Tumin, S. A. 2019. The status of the paddy and rice industry in Malaysia. Khazanah Research Institute, Kuala Lumpur, Malaysia. 203 pp.

Chithrashree, Udayashankar, A. C., Chandra Nayaka, S., Reddy, M. S. and Srinivas, C. 2011. Plant growth-promoting rhizobacteria mediate induced systemic resistance in rice against bacterial leaf blight caused by Xanthomonas oryzae pv. oryzae. Biol. Control 59:114-122.

Ferraz, H. G. M., Resende, R. S., Moreira, P. C., Silveira, P. R., Milagres, E. A., Oliveira, J. R. and Rodrigues, F. Á. 2015. Antagonistic rhizobacteria and jasmonic acid induce resistance against tomato bacterial spot. Bragantia 74:417-427.

Furumo, N. C. and Furutani, S. 2008. A simple method for assaying total protein, polyphenol oxidase and peroxidase activity from 'Kaimana' Litchi chinensis Sonn. J. Hawaii. Pac. Agric. 15:1-7.

Gopalakrishnan, S., Vadlamudi, S., Bandikinda, P., Sathya, A., Vijayabharathi, R., Rupela, O., Kudapa, H., Katta, K. and Varshney, R. K. 2013. Evaluation of Streptomyces strains 
isolated from herbal vermicompost for their plant growthpromotion traits in rice? Microbiol. Res. 169:40-48.

Hastuti, R. D., Lestari, Y., Suwanto, A. and Saraswati, R. 2012. Endophytic Streptomyces spp. as biocontrol agents of rice bacterial leaf blight pathogen (Xanthomonas oryzae pv. oryzae). HAYATI J. Biosci. 19:155-162.

Hata, E. M., Sijam, K., Mior Ahmad, Z. A., Yusof, M. T. and Azman, N. A. 2015. In vitro antimicrobial assay of actinomycetes in rice against Xanthomonas oryzae pv. oryzicola and as potential plant growth promoter. Braz. Arch. Biol. Technol. 58:821-832.

Hata, E. M., Sijam, K., Yusof, M. T. and Zulperi, D. 2019. Occurrence of Xanthomonas oryzae pv. oryzicola causing bacterial leaf streak disease of rice in different state of Malaysia. $J$. Plant Pathol. 101:785-786.

Herman, T., Murchie, E. H. and Warsi, A. A. 2015. Rice production and climate change: a case study of Malaysian rice. Pertanika J. Trop. Agric. Sci. 38:321-328.

International Rice Research Institute. 1996. Standard evaluation system for rice. 4th ed. International Rice Research Institute, Manila, Philippines. 52 pp.

Jha, C. K. and Saraf, M. 2012. Evaluation of multispecies plantgrowth-promoting consortia for the growth promotion of Jatropha curcas L. J. Plant Growth Regul. 31:588-598.

Ji, G.-H., Wei, L.-F., He, Y.-Q., Wu, Y.-P. and Bai, X.-H. 2008. Biological control of rice bacterial blight by Lysobacter antibioticus strain 13-1. Biol. Control 45:288-296.

Khan, M. A., Naeem, M. and Iqbal, M. 2014. Breeding approaches for bacterial leaf blight resistance in rice (Oryza sativa L.), current status and future directions. Eur. J. Plant Pathol. 139:27-37.

Kurth, F., Mailänder, S., Bönn, M., Feldhahn, L., Herrmann, S., Große, I., Buscot, F., Schrey, S. D. and Tarkka, M. T. 2014. Streptomyces-induced resistance against oak powdery mildew involves host plant responses in defense, photosynthesis, and secondary metabolism pathways. Mol. Plant-Microbe Interact. 27:891-900.

Lee, H.-J., Park, K.-H., Shim, J.-H., Park, R.-D., Kim, Y.-W., Cho, J.-Y., Hwangbo, H., Kim, Y.-C., Cha, G.-S. Krishnan, H.-B. and Kim, K.-Y. 2005. Quantitative changes of plant defense enzymes in biocontrol of pepper (Capsicium annuum L.) late blight by antagonistic Bacillus subtilis HJ927. J. Microbiol. Biotechnol. 15:1073-1079.

Lever, M. 1972. A new reaction for colorimetric determination of carbohydrates. Anal. Biochem. 47:273-279.

Liu, W., Liu, J., Triplet, L., Leach, J. E. and Wang, G.-L. 2014. Novel insights into rice innate immunity against bacterial and fungal pathogens. Annu. Rev. Phytopathol. 52:213-241.

Niño-Liu, D. O., Ronald, P. C. and Bogdanove, A. J. 2006. Xanthomonas oryzae pathovars: model pathogens of a model crop. Mol. Plant Pathol. 7:303-324.

Olanrewaju, O. S. and Babalola, O. O. 2019. Streptomyces: implications and interactions in plant growth promotion. Appl. Microbiol. Biotechnol. 103:1179-1188.
Oluwambe, T. M. and Kofoworola, A. A. 2016. Comparison of single culture and the consortium of growth-promoting rhizobacteria from three tomato (Lycopersicon esculentum Mill) varieties. Adv. Plants Agric. Res. 5:448-455.

Ouhdouch, Y., Barakate, M. and Finance, C. 2001. Actinomycetes of Moroccan habitats: isolation and screening for antifungal activities. Eur. J. Soil Biol. 37:69-74.

Pal, K. K. and Gardener, B. M. 2006. Biological control of plant pathogens. URL https://www.apsnet.org/edcenter/disimpactmngmnt/topc/Documents/PHI-BiologicalControl.pdf [14 January 2019].

Pieterse, C. M. J., Zamioudis, C., Berendsen, R. L., Weller, D. M., Van Wees, S. C. M. and Bakker, P. A. H. M. 2014. Induced systemic resistance by beneficial microbes. Annu. Rev. Phytopathol. 52:347-375.

Poulin, L., Raveloson, H., Sester, M., Raboin, L.-M., Silué, D., Koebnik, R. and Szurek, B. 2014. Confirmation of bacterial leaf streak caused by Xanthomonas oryzae pv. oryzicola on rice in Madagascar. Plant Dis. 98:1423.

Rahman, A., Hosokawa, S., Oono, Y., Amakawa, T., Goto, N. and Tsurumi, S. 2002. Auxin and ethylene response interactions during arabidopsis root hair development dissected by auxin influx modulators. Plant Physiol. 130:1908-1917.

Rais, A., Jabeen, Z., Shair, F., Hafeez, F. Y. and Hassan, M. N. 2017. Bacillus spp., a bio-control agent enhances the activity of antioxidant defense enzymes in rice against Pyricularia oryzae. PLoS ONE 12:e187412.

Sharma, M., Dangi, P. and Choudhary, M. 2014. Actinomycetes: source, identification, and their applications. Int. J. Curr. Microbiol. Appl. Sci. 3:801-832.

Singh, R. A. and Rao, M. H. S. 1977. A simple technique for detecting Xanthomonas oryzae in rice seeds. Seed Sci. Technol. 5:123-127.

Sreevidya, M., Gopalakrishnan, S., Kudapa, H. and Varshney, R. K. 2016. Exploring plant growth-promotion actinomycetes from vermicompost and rhizosphere soil for yield enhancement in chickpea. Braz. J. Microbiol. 47:85-95.

Suárez-Moreno, Z. R., Vinchira-Villarraga, D. M., VergaraMorales, D. I., Castellanos, L., Ramos, F. A., Guarnaccia, C., Degrassi, G., Venturi, V. and Moreno-Sarmiento, N. 2019. Plant-growth promotion and biocontrol properties of three Streptomyces spp. isolates to control bacterial rice pathogens. Front. Microbiol. 10:290.

Van Loon, L. C. and Bakker, P. A. H. M. 2006. Induced systemic resistance as a mechanism of disease suppression by rhizobacteria. In: PGPR: biocontrol and biofertilization, ed. by $\mathrm{Z}$. A. Siddiqui, pp. 39-66. Springer, Dordrecht, The Netherlands.

Viaene, T., Langendries, S., Beirinckx, S., Maes, M. and Goormachtig, S. 2016. Streptomyces as a plant's best friend? FEMS Microbiol. Ecol. 92:fiw119.

Vurukonda, S., Giovanardi, D. and Stefani, E. 2018. plant growth promoting and biocontrol activity of Streptomyces spp. as Endophytes. Int. J. Mol. Sci. 19:952.

Xu, Y., Zhu, X.-F., Zhou, M.-G., Kuang, J., Zhang, Y., Shang, 
Y. and Wang, J.-X. 2010. Status of streptomycin resistance development in Xanthomonas oryzae pv. oryzae and Xanthomonas oryzae pv. oryzicola in China and their resistance characters. J. Phytopathol. 158:601-608.

Yang, C.-M. 2010. Assessment of the severity of bacterial leaf blight in rice using canopy hyperspectral reflectance. Precis. Agric. 11:61-81.

Yi, H. S., Yang, J. W. and Ryu, C. M. 2013. ISR meets SAR outside: additive action of the endophyte Bacillus pumilus
INR7 and the chemical inducer, benzothiadiazole, on induced resistance against bacterial spot in field-grown pepper. Front. Plant Sci. 4:122.

Zuki, Z. M., Rafii, M. Y., Ramli, A., Oladosu, Y., Abdul Latif, M., Sijam, K., Ismail, M. R. and Mohd Sarif, H. 2020. Segregation analysis for bacterial leaf blight disease resistance genes in rice 'MR219' using SSR marker. Chil. J. Agric. Res. 80:227-233. 